\title{
NEUTRALIZATION TESTS IN POLIOMYELITIS. SERA TAKEN \\ DURING THE ACUTE AND CONVALESCENT STAGES OF THE \\ DISEASE AND TESTED WITH A PASSAGE VIRUS AND A \\ STRAIN ISOLATED DURING THE 1935 NEW YORK CITY \\ OUTBREAK ${ }^{1}$
}

\author{
By MAURICE BRODIE, ALFRED E. FISCHER AND MAXWELL STILLERMAN \\ (From the Willard Parker Hospital, Department of Hospitals, and the Department of \\ Bacteriology, New York University Medical College, New York City)
}

(Received for publication January 9, 1937)

It has generally been accepted that recovery from paralytic poliomyelitis usually results in the appearance of antibodies in the blood serum ( 1 to 10). The neutralizing property of human convalescent sera from paralytic patients was first demonstrated in 1910 by Netter and Levaditi (1) and by Flexner and Lewis (2). Since then a number of investigators have confirmed this find- recorded by several of the early workers. Recently, however, the absence of neutralizing power in convalescent sera has been noted more frequently (16 to 19). The majority of the neutralization tests were performed upon sera obtained from patients years after the onset of the disease; a smaller number were carried out on sera collected within one year; a few were secured

TABLE I

Summary of neutralization tests in paralytic cases compiled from the literature

\begin{tabular}{|c|c|c|c|c|c|c|c|c|c|}
\hline \multirow[b]{2}{*}{ Investigators } & \multicolumn{3}{|c|}{ Within one week of onset } & \multicolumn{3}{|c|}{ Within one year of onset } & \multicolumn{3}{|c|}{ More than one year after onset } \\
\hline & $\begin{array}{c}\text { Number } \\
\text { of cases } \\
\text { tested }\end{array}$ & $\begin{array}{c}\text { Number } \\
\text { neutral- } \\
\text { ized }\end{array}$ & $\begin{array}{c}\text { Number } \\
\text { failed to } \\
\text { neutralize }\end{array}$ & $\begin{array}{c}\text { Number } \\
\text { of cases } \\
\text { tested }\end{array}$ & $\begin{array}{c}\text { Number } \\
\text { neutral- } \\
\text { ized }\end{array}$ & $\begin{array}{l}\text { Number } \\
\text { failed to } \\
\text { neutralize }\end{array}$ & $\begin{array}{c}\text { Number } \\
\text { of cases } \\
\text { tested }\end{array}$ & $\begin{array}{c}\text { Number } \\
\text { neutral- } \\
\text { ized }\end{array}$ & $\begin{array}{l}\text { Number } \\
\text { failed to } \\
\text { neutralize }\end{array}$ \\
\hline 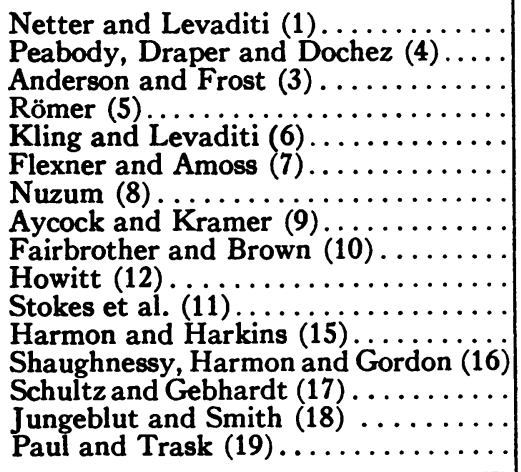 & $\begin{array}{l}2 \\
1\end{array}$ & $\begin{array}{l}2 \\
1\end{array}$ & $\begin{array}{l}0 \\
0\end{array}$ & $\begin{array}{l}4 \\
1 \\
1 \\
2 \\
2 \\
\\
1^{*} \\
1 \\
1\end{array}$ & $\begin{array}{l}4 \\
1 \\
1 \\
2 \\
2 \\
\\
0 \\
0 \\
1\end{array}$ & $\begin{array}{l}0 \\
0 \\
0 \\
0 \\
0 \\
\\
1 \\
1 \\
0\end{array}$ & $\begin{array}{r}16 \\
20 \\
2 \\
\\
10 \\
4 \\
26\end{array}$ & $\begin{array}{r}15 \\
9 \\
1 \\
7 \\
2 \\
15\end{array}$ & $\begin{array}{r}1 \\
11 \\
1 \\
3 \\
2 \\
11\end{array}$ \\
\hline Total. & 6 & 4 & 2 & 29 & 18 & 11 & 84 & 53 & 31 \\
\hline
\end{tabular}

* Recently recovered.

ing (Table I). This tabulation does not include tests performed on pooled convalescent sera or on sera of patients who had received serum therapy (11 to 15). An occasional failure of convalescent serum to neutralize poliomyelitis virus was

1 This work was made possible by grants from the Rockefeller Foundation and the President's Birthday Commission for Infantile Paralysis Research. during the first week of illness. The proportion of patients showing neutralizing substances was approximately the same, regardless of the time after the onset of the disease that the sera were collected (Table I). This would suggest that the neutralizing substances either developed shortly after the onset of the disease or were present at the time of the infection. The former idea was 
supported by Kling and Levaditi (6) who found neutralizing substances three and five days after the onset of the disease, and by Flexner and Amoss (7) who reported a similar finding at six days. The latter possibility was favored by Harmon and coworkers (14) who found neutralizing substances present in the serum of a patient before the onset of paralysis.

The higher incidence of neutralizing substances found in the convalescent sera by the early workers might have been due to chance in dealing with small numbers or to differences in technique of performing the tests. The age of the patient and the virulence of the virus must also be considered.

Very few studies have been carried out on sera from non-paralytic patients. Peabody, Draper and Dochez (4) found no neutralizing power in the serum of a child 7 days after the onset of the disease, while that of another child neutralized at 21 days. Paul and Trask (19) reported the case of a 6 year old non-paralytic child whose serum failed to neutralize both in the acute stage and 1 year later. Harmon and Harkins (15) demonstrated the presence of neutralizing substances in the serum from an 11 year old child obtained 5 days and again 5 months after the onset of the disease. Neutralization tests have also been recorded by several other investigators $(1,3,5,6)$ upon blood from patients about whom insufficient clinical data were given to determine whether they could be classified as non-paralytic or abortive cases of poliomyelitis.

Neutralizing substances have frequently been reported in the sera of so-called normal individuals $(9,16,20)$. The incidence of these antibodies appears to increase with age $(9,16)$. Various workers $(9,16,20)$ have found that the sera of at least 50 per cent of normal adults have neutralizing power. Paul and Trask (21) in a review of reports on neutralization tests carried out since 1929 , pointed out that the neutralizing power of normal sera exceeded that of convalescent sera in all age groups.

All of the above recorded tests were performed with a monkey passage virus. In addition, Paul and Trask (19) tested 7 sera with a recently isolated human strain of virus, as well as with a passage strain. They found that neutralizing substances were present in 6 of the 7 sera tested with the former strain as compared to one with the latter. Likewise, Howitt (22) found that 7 convalescent sera neutralized a recently isolated strain, while only 4 of them neutralized a passage virus.

In spite of so much contradictory evidence, the idea still prevails that recovery from an attack of poliomyelitis results in the development of antibodies. It, therefore, seemed advisable to investigate the matter further by tests on a sufficiently large number of sera taken at frequent intervals following the onset of the disease.

The purpose of this work was: (1) To test for the presence or absence of neutralizing substances in the sera of both paralytic and non-paralytic individuals of different ages in the acute and convalescent stages of the disease; (2) To determine whether poliomyelitis can develop in the presence of protective substances; (3) To determine whether paralytic or non-paralytic cases with no demonstrable protective substances in the acute stage of the disease developed them within 12 to 16 months after the onset; (4) To carry out the above tests with the $F 1$ passage virus and with a strain of virus isolated during the summer of 1935.

\section{METHODS}

Sera were obtained from patients who were admitted to the Willard Parker Hospital for poliomyelitis during the summer and fall of 1935, when over 2,000 cases were reported in New York City. In each instance the diagnosis was established by clinical findings and examination of spinal fluids. Only those patients who had a definite loss of muscle function were classified as paralytic. Nonparalytic cases were those who had an acute onset with meningeal involvement and pleocytosis of the spinal fluid. Every case was seen by one of us and a careful follow-up of the non-paralytic and the paralytic patients was carried out. In this way, it was possible to eliminate from the non-paralytic group those patients who subsequently developed muscle weakness or paralysis. We also correlated, in the paralytics, the degree of muscle recovery with the results of the neutralization tests.

The work was begun in July 1935, and the patients were bled at short intervals during the following 9 months. A number were also bled 12 to 16 months after the onset. The majority of the sera were tested within a few weeks after collection. When comparative tests between early and later bleedings were made, the sera, which had been stored for 6 to 7 months, were again tested. All specimens were cultured before use and were kept at $2^{\circ}$ to $4^{\circ} \mathrm{C}$.

Passage virus and preparation of suspension. The passage virus (F1 strain) was ground without abrasive, 
suspended in an equal amount of glycerine (Kahlbaum) by weight, and kept frozen. Small portions were removed, ground with sand, and to each gram was added $10 \mathrm{cc}$. of distilled water to make a 10 per cent suspension. The suspension was centrifuged lightly, and the resulting supernatant was referred to as a 5 per cent cord suspension because half of the gram of material mixed with the water was glycerine. Five different batches of infectious cords, each consisting of 4 or 5 spinal cords obtained from monkeys at the height of paralysis, were used. Four of the batches were used from July to November 1935, and the fifth from then until the completion of the work in October 1936. The virus, stored in this way, maintained its potency at a fairly uniform level of infectivity, as indicated by the results of repeated tests carried out with a batch over a period of 12 months.

The infectivity of each batch of virus was determined by making serial dilutions of the 5 per cent suspension with distilled water. This was accomplished by the addition of 0.5 to $1.0 \mathrm{cc}$. of virus suspension to the required amount of diluent, and then after being shaken for several minutes, $0.13 \mathrm{cc}$. was measured off with a $0.2 \mathrm{cc}$. pipette. Usually, $0.13 \mathrm{cc}$. of a 5 per cent suspension diluted 40 to 80 times and added to $0.6 \mathrm{cc}$. of saline or normal monkey serum resulted in infection.

Recently isolated strain. The virus was obtained from the nasal secretions of an acute bulbar case of poliomyelitis on the 9th day of illness. The washings were passed through a Seitz filter and concentrated in vacuo to approximately $5 \mathrm{cc}$. This was then inoculated intracerebrally and intraperitoneally into a monkey. For the tests described in this paper a single cord from the second passage was used, being kept in glycerine at freezing temperature. In making up the virus suspension, small pieces from 6 to 8 segments were used as previously described (23). The infectivity of the cord was sufficient to produce a rapid and complete paralysis in the usual incubation period when $0.13 \mathrm{cc}$. of a 5 per cent suspension diluted 20 to 40 times was injected. The virulence of this strain was, therefore, comparable to that of the passage virus.

Neutralization test. The neutralization or protection test was carried out as follows : $0.13 \mathrm{cc}$. of a $1: 10$ or $1: 2$ dilution of 5 per cent virus was added to $0.6 \mathrm{cc}$. of serum; the proportion was $0.1 \mathrm{cc}$. of diluted virus suspension to $0.45 \mathrm{cc}$. of serum. The mixtures were incubated for 2 hours at $37^{\circ} \mathrm{C}$. and then kept in the ice box for approximately 2 hours. Of this mixture 0.5 to $0.6 \mathrm{cc}$. was inoculated into the frontal lobe of a monkey. A positive control, consisting of human serum known to have protective substances, was used in each experiment. Likewise, a negative control, consisting of normal monkey serum without protective properties, was included. When the serum failed to protect, the animal became paralyzed. With few exceptions, once paralysis set in, the animals became prostrate. When the paralysis was definite but failed to involve all extremities, it was referred to as "incomplete paralysis."

The usual minimal dose which was used to test the sera in this work was $0.13 \mathrm{cc}$. of a $1: 10$ dilution of 5 per cent virus suspension. If the serum protected, a $1: 2$ dilution of the virus suspension was used in the next test. Protective substances were considered present only when the animal survived the greater dose. A more concentrated virus suspension was used to offset the irregularities which can occur in carrying out tests with small amounts of virus. When irregularities occurred, several retests were made and the average result recorded. Some of the sera were tested with as many as $\mathbf{3}$ different batches of virus with fairly consistent results.

Macacus rhesus monkeys weighing 21/2 to 4 kilos were used. Those surviving were not used again within the month. After an animal was used 3 times, it was injected with 0.13 cc. of a $1: 10$ or $1: 2$ dilution of a 5 per cent virus suspension added to $0.6 \mathrm{cc}$. of saline or normal monkey serum to determine whether the protection tests carried out upon the monkey were valid. This was necessary because an occasional monkey is naturally resistant. Daily temperatures were taken for at least two weeks after inoculation.

\section{EXPERIMENTAL}

The sera of 82 paralytic, 32 non-paralytic and 3 encephalitic cases were tested in the acute stage of the disease, that is, within a week after the onset. Many of the sera were retested at intervals during convalescence. Thirty-three experiments were carried out. The following 9 were selected as typical protocols.

\section{Neutralization tests with sera obtained in the acute stages of the disease}

Experiment 1. The sera of 16 paralytic and 13 non-paralytic patients ranging from 5 months to 28 years of age were tested. It was found (Table II) that the sera of 6 of 7 paralytics 5 years and under and 2 non-paralytics in the same age group, failed to neutralize a $1: 10$ dilution of a 5 per cent virus suspension. In the group over 5 years the sera of 8 of 9 paralytics failed to protect; all these were tested with a 1:2 dilution of virus suspension. On the other hand, the sera of 9 of 11 non-paralytics over 5 years of age neutralized either a $1: 10$ or a $1: 2$ dilution; seven of them were tested against the $1: 2$ dilution of virus.

Experiment 2. Certain sera of the first and other experiments which had given protection with a given test dose of virus, were retested with larger doses. Sera that previously had neutralized $0.13 \mathrm{cc}$. of a $1: 10$ dilution were retested with a $1: 2$ dilution of a 5 per cent virus suspension; and those that had neutralized the latter amount 
TABLE II

Summary of neutralization tests with sera taken in the first week of the disease

\begin{tabular}{|c|c|c|c|c|c|c|c|c|}
\hline Patient's initials & Age & Type of case & $\begin{array}{l}\text { Time } \\
\text { after } \\
\text { onset }\end{array}$ & $\begin{array}{c}\text { Dilu- } \\
\text { tion of } \\
5 \text { per } \\
\text { cent } \\
\text { virus }\end{array}$ & $\begin{array}{l}\text { Amount } \\
\text { of } \\
\text { virus }\end{array}$ & $\begin{array}{l}\text { Amount } \\
\text { of } \\
\text { serum }\end{array}$ & $\begin{array}{c}\text { Number } \\
\text { of } \\
\text { monkey }\end{array}$ & Results \\
\hline ve control. & \multicolumn{3}{|c|}{ Normal monkey serum } & $1: 10$ & $\begin{array}{l}c c . \\
0.13\end{array}$ & $\begin{array}{ll}c c . \\
0.60\end{array}$ & $\mathrm{~J} 127$ & Paralyzed 7 days \\
\hline Negative control. & \multicolumn{3}{|c|}{ Normal monkey serum } & $1: 2$ & 0.13 & 0.60 & J 35 & Paralyzed 7 days \\
\hline e control. . & \multicolumn{3}{|c|}{ Normal adult human serum (M.B.) } & * & 0.20 & 0.45 & J 1219 & No paralysis \\
\hline Positive control ........ & \multicolumn{3}{|c|}{ Normal adult human serum (M.B.) } & * & 0.45 & 0.45 & 617 & Paralyzed 11 days \\
\hline$\ldots \ldots \ldots \ldots \ldots \ldots \ldots \ldots \ldots \ldots \ldots$ & $\begin{array}{l}5 \text { mos. } \\
16 \text { mos. } \\
\text { years }\end{array}$ & $\begin{array}{l}\text { Paralytic } \\
\text { Paralytic }\end{array}$ & $\begin{array}{l}7 \\
3\end{array}$ & $\begin{array}{l}1: 10 \\
1: 10\end{array}$ & $\begin{array}{l}0.13 \\
0.13\end{array}$ & $\begin{array}{l}0.60 \\
0.60\end{array}$ & $\begin{array}{l}\text { J } 92 \\
\text { J } 107\end{array}$ & $\begin{array}{l}\text { Paralyzed } 10 \text { days } \\
\text { Paralyzed } 6 \text { days }\end{array}$ \\
\hline 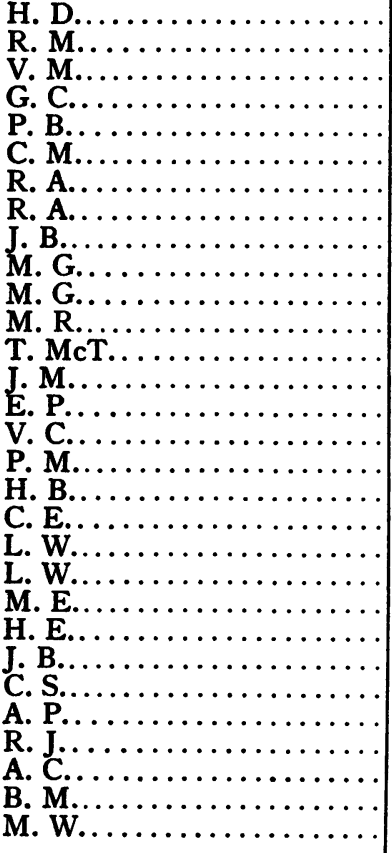 & $\begin{array}{r}2 \\
4 \\
4 \\
5 \\
5 \\
6 \\
7 \\
7 \\
8 \\
8 \\
8 \\
9 \\
15 \\
16 \\
21 \\
28 \\
3 \\
5 \\
6 \\
8 \\
8 \\
9 \\
10 \\
13 \\
15 \\
16 \\
16 \\
16 \\
22 \\
27\end{array}$ & $\begin{array}{c}\text { Paralytic } \\
\text { Paralytic } \\
\text { Paralytic } \\
\text { Paralytic } \\
\text { Paralytic } \\
\text { Paralytic } \\
\text { Paralytic } \\
\text { Paralytic } \\
\text { Paralytic } \\
\text { Paralytic } \\
\text { Paralytic } \\
\text { Paralytic } \\
\text { Paralytic } \\
\text { Paralytic } \\
\text { Paralytic } \\
\text { Paralytic } \\
\text { Non-paralytic } \\
\text { Non-paralytic } \\
\text { Non-paralytic } \\
\text { Non-paralytic } \\
\text { Non-paralytic } \\
\text { Non-paralytic } \\
\text { Non-paralytic } \\
\text { Non-paralytic } \\
\text { Non-paralytic } \\
\text { Non-paralytic } \\
\text { Non-paralytic } \\
\text { Non-paralytic } \\
\text { Non-paralytic } \\
\text { Non-paralytic }\end{array}$ & $\begin{array}{l}4 \\
5 \\
3 \\
5 \\
3 \\
5 \\
2 \\
2 \\
1 \\
3 \\
3 \\
4 \\
6 \\
4 \\
4 \\
1 \\
7 \\
3 \\
3 \\
2 \\
2 \\
3 \\
3 \\
1 \\
2 \\
2 \\
4 \\
6 \\
2 \\
4\end{array}$ & $\begin{array}{l}1: 10 \\
1: 10 \\
1: 10 \\
1: 10 \\
1: 10 \\
1: 2 \\
1: 10 \\
1: 2 \\
1: 2 \\
1: 10 \\
1: 2 \\
1: 2 \\
1: 2 \\
1: 2 \\
1: 2 \\
1: 2 \\
1: 10 \\
1: 10 \\
1: 10 \\
1: 10 \\
1: 2 \\
1: 2 \\
1: 10 \\
1: 2 \\
1: 2 \\
1: 2 \\
1: 2 \\
1: 2 \\
1: 2 \\
1: 2\end{array}$ & $\begin{array}{l}0.13 \\
0.13 \\
0.13 \\
0.13 \\
0.13 \\
0.13 \\
0.13 \\
0.13 \\
0.13 \\
0.13 \\
0.13 \\
0.13 \\
0.13 \\
0.13 \\
0.13 \\
0.13 \\
0.13 \\
0.13 \\
0.13 \\
0.13 \\
0.13 \\
0.13 \\
0.13 \\
0.13 \\
0.13 \\
0.13 \\
0.13 \\
0.13 \\
0.13 \\
0.13\end{array}$ & $\begin{array}{l}0.60 \\
0.60 \\
0.60 \\
0.60 \\
0.60 \\
0.60 \\
0.60 \\
0.60 \\
0.60 \\
0.60 \\
0.60 \\
0.60 \\
0.60 \\
0.60 \\
0.60 \\
0.60 \\
0.60 \\
0.60 \\
0.60 \\
0.60 \\
0.60 \\
0.60 \\
0.60 \\
0.60 \\
0.60 \\
0.60 \\
0.60 \\
0.60 \\
0.60 \\
0.60\end{array}$ & $\begin{array}{ll}\mathrm{J} & 124 \\
\mathrm{~J} & 108 \\
\mathrm{~J} & 102 \\
\mathrm{~J} & 112 \\
\mathrm{~J} & 111 \\
\mathrm{~J} & 122 \\
\mathrm{~J} & 120 \\
\mathrm{~J} & 119 \\
\mathrm{~J} & 105 \\
\mathrm{~J} & 121 \\
\mathrm{~J} & 53 \\
\mathrm{~J} & 103 \\
\mathrm{~J} & 90 \\
\mathrm{~J} & 91 \\
\mathrm{~J} & 97 \\
\mathrm{~J} & 93 \\
\mathrm{~J} & 100 \\
\mathrm{~J} & 113 \\
\mathrm{~J} & 114 \\
\mathrm{~J} & 123 \\
\mathrm{~J} & 70 \\
\mathrm{~J} & 96 \\
\mathrm{~J} & 115 \\
\mathrm{~J} & 98 \\
\mathrm{~J} & 99 \\
\mathrm{~J} & 95 \\
\mathrm{~J} & 106 \\
\mathrm{~J} & 128 \\
\mathrm{~J} & 104 \\
\mathrm{~J} & 94 \\
& \end{array}$ & $\begin{array}{l}\text { No paralysis } \\
\text { Paralyzed } 9 \text { days } \\
\text { Paralyzed } 9 \text { days } \\
\text { Paralyzed } 6 \text { days } \\
\text { Paralyzed } 14 \text { days } \\
\text { Paralyzed } 8 \text { days } \\
\text { No paralysis } \\
\text { No paralysis } \\
\text { Paralyzed } 7 \text { days } \\
\text { Paralyzed } 15 \text { days } \\
\text { Paralyzed } 8 \text { days } \\
\text { Paralyzed } 16 \text { days } \\
\text { Paralyzed } 6 \text { days } \\
\text { Paralyzed } 6 \text { days } \\
\text { Paralyzed } 6 \text { days } \\
\text { Paralyzed } 6 \text { days } \\
\text { Paralyzed } 7 \text { days } \\
\text { Paralyzed } 4 \text { days } \\
\text { No paralysis } \\
\text { No paralysis } \\
\text { No paralysis } \\
\text { No paralysis } \\
\text { No paralysis } \\
\text { No paralysis } \\
\text { Paralyzed } 9 \text { days } \\
\text { No paralysis } \\
\text { No paralysis } \\
\text { Paralyzed } 16 \text { days } \\
\text { No paralysis } \\
\text { No paralysis }\end{array}$ \\
\hline
\end{tabular}

* Undiluted.

were tested with $0.13 \mathrm{cc}$. or more of a 5 per cent suspension. The results (Table III) showed that the sera of 5 of 8 non-paralytics and two paralytics protected when the larger quantity of virus was used.

\section{Summary of results of all tests on sera collected in the acute stage of the disease}

The results of all of the first-week bleedings (Table IV) indicated that protective substances were present in 14 of 82 paralytics during the acute stage of the disease. In the non-paralytic group, on the other hand, they were present in
18 of 32 sera. When protective substances were present, they were detected as early as 1 and 2 days after the onset of the disease both in paralytic and non-paralytic cases. Four of the 82 patients were tested in the preparalytic stage. Two of them were found to have protective substances.

\section{Protective substances in normal urban individuals}

It was decided to test sera of a group of socalled normal residents of New York City between 11 and 25 years of age to determine whether the virus and technique used in the 
TABLE III

Neutralization tests in the first week of the disease. (These sera had previously neutralized a smaller dose of virus)

\begin{tabular}{|c|c|c|c|c|c|c|c|c|}
\hline Patient's initials & Age & Type of case & $\begin{array}{l}\text { Time } \\
\text { after } \\
\text { onset }\end{array}$ & $\begin{array}{c}\text { Dilu- } \\
\text { tion of } \\
5 \text { per } \\
\text { cent } \\
\text { virus }\end{array}$ & $\begin{array}{c}\text { Amount } \\
\text { of } \\
\text { virus }\end{array}$ & $\begin{array}{c}\text { Amount } \\
\text { of } \\
\text { serum }\end{array}$ & $\begin{array}{c}\text { Number } \\
\text { of } \\
\text { monkey }\end{array}$ & Results \\
\hline Negative control. & \multicolumn{3}{|c|}{ Normal monkey serum } & $1: 10$ & $\begin{array}{c}c c . \\
0.13\end{array}$ & $\begin{array}{c}c c . \\
0.60\end{array}$ & J 207 & Paralyzed 7 days \\
\hline Negative control. & \multicolumn{3}{|c|}{ Normal monkey serum } & $1: 2$ & 0.13 & 0.60 & $\mathrm{~J} 126$ & Paralyzed 6 days \\
\hline Positive control. & \multicolumn{3}{|c|}{ Normal adult human serum (M.B.) } & * & 0.20 & 0.45 & J 208 & Partial paralysis \\
\hline Positive control .......... & \multicolumn{3}{|c|}{ Normal adult human serum (M.B.) } & $1: 2$ & 0.13 & 0.60 & J 215 & No paralysis \\
\hline 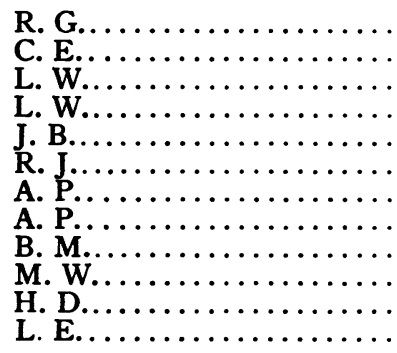 & $\begin{array}{r}3 \\
6 \\
8 \\
8 \\
13 \\
16 \\
16 \\
16 \\
22 \\
27 \\
2 \\
8\end{array}$ & $\begin{array}{c}\text { Non-paralytic } \\
\text { Non-paralytic } \\
\text { Non-paralytic } \\
\text { Non-paralytic } \\
\text { Non-paralytic } \\
\text { Non-paralytic } \\
\text { Non-paralytic } \\
\text { Non-paralytic } \\
\text { Non-paralytic } \\
\text { Non-paralytic } \\
\text { Paralytic } \\
\text { Paralytic }\end{array}$ & $\begin{array}{l}4 \\
3 \\
2 \\
2 \\
1 \\
4 \\
2 \\
2 \\
2 \\
4 \\
5\end{array}$ & $\begin{array}{c}1 \\
1: 2 \\
* \\
* \\
* \\
* \\
* \\
* \\
* \\
* \\
1: 2 \\
1: 2\end{array}$ & $\begin{array}{l}0.20 \\
0.13 \\
0.20 \\
0.45 \\
0.20 \\
0.20 \\
0.20 \\
0.45 \\
0.20 \\
0.20 \\
0.13 \\
0.13\end{array}$ & $\begin{array}{l}0.45 \\
0.45 \\
0.45 \\
0.45 \\
0.45 \\
0.45 \\
0.45 \\
0.45 \\
0.45 \\
0.45 \\
0.60 \\
0.60\end{array}$ & \begin{tabular}{|ll}
$J$ & 239 \\
$\mathrm{~J}$ & 234 \\
$\mathrm{~J}$ & \\
$\mathrm{~J}$ & 229 \\
$\mathrm{~N}$ & 17 \\
$\mathrm{~N}$ & 19 \\
$\mathrm{~J}$ & 119 \\
$\mathrm{~J}$ & 211 \\
$\mathrm{~J}$ & 237 \\
$\mathrm{~N}$ & 8 \\
$\mathrm{~J}$ & 220 \\
$\mathrm{~J}$ & 216
\end{tabular} & $\begin{array}{l}\text { No paralysis } \\
\text { Paralyzed } 15 \text { days } \\
\text { No paralysis } \\
\text { No paralysis } \\
\text { No paralysis } \\
\text { Paralyzed } 7 \text { days } \\
\text { No paralysis } \\
\text { No paralysis } \\
\text { No paralysis } \\
\text { Paralyzed } 9 \text { days } \\
\text { No paralysis } \\
\text { No paralysis }\end{array}$ \\
\hline
\end{tabular}

* Undiluted.

experiments produced approximately the same proportion of neutralizations reported by others $(9,16,21)$. Moreover, this would enable us also to compare the results of these tests with those of paralytic and non-paralytic patients in the acute stage of the disease.

TABLE IV

Summary of neutralization tests with sera taken in the first week of the disease

\begin{tabular}{|c|c|c|c|c|c|c|c|c|c|}
\hline \multirow[b]{2}{*}{$\underset{\text { group }}{\text { Age }}$} & \multicolumn{3}{|c|}{ Paralytics } & \multicolumn{3}{|c|}{ Non-paralytics } & \multicolumn{3}{|c|}{ Encephalitic } \\
\hline & 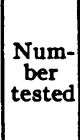 & $\begin{array}{l}\text { Sera } \\
\text { neu- } \\
\text { tral- } \\
\text { ized }\end{array}$ & $\begin{array}{c}\text { Sera } \\
\text { failed } \\
\text { to } \\
\text { neu- } \\
\text { tral- } \\
\text { ize }\end{array}$ & $\begin{array}{l}\text { Num- } \\
\text { ber } \\
\text { tested }\end{array}$ & $\mid \begin{array}{l}\text { Sera } \\
\text { neu- } \\
\text { tral- } \\
\text { ized }\end{array}$ & $\begin{array}{c}\text { Sera } \\
\text { failed } \\
\text { to } \\
\text { neu- } \\
\text { tral- } \\
\text { ize }\end{array}$ & $\underset{\begin{array}{c}\text { Num- } \\
\text { tested }\end{array}}{\text { Num }}$ & $\begin{array}{l}\text { Sera } \\
\text { neu- } \\
\text { tral- } \\
\text { ized }\end{array}$ & $\begin{array}{c}\text { Sera } \\
\text { failed } \\
\text { to } \\
\text { neu- } \\
\text { tral- } \\
\text { ize }\end{array}$ \\
\hline $\begin{array}{c}\text { years } \\
1-5 \ldots . . \\
6-10 \ldots \\
11-17 \ldots \\
\text { Adults. } \\
\text { Totals . }\end{array}$ & $\begin{array}{l}26 \\
25 \\
19 \\
12 \\
82\end{array}$ & $\begin{array}{r}2 \\
4 \\
4 \\
4 \\
14\end{array}$ & $\begin{array}{r}24 \\
21 \\
15 \\
8 \\
68\end{array}$ & $\begin{array}{r}6 \\
14 \\
10 \\
2 \\
32\end{array}$ & $\begin{array}{r}1 \\
10 \\
5 \\
2 \\
18\end{array}$ & $\begin{array}{r}5 \\
4 \\
5 \\
\theta \\
14\end{array}$ & 3 & 1 & 2 \\
\hline
\end{tabular}

Experiment 3. The sera of 18 individuals from 11 to 25 years of age were tested by the use of $0.6 \mathrm{cc}$. of serum mixed with $0.13 \mathrm{cc}$. of a 21/2 per cent (a $1: 2$ dilution of 5 per cent) virus suspension. Protection occurred with 9 of the 18 sera. The proportion of positive neutralizations in the group approximates that found by other workers for normal urban adolescents and adults. Protective substances were found in only 8 of the 31 sera from paralytic patients over 10 years of age during the acute stage (Table IV). In the non-paralytic patients of the same age group, 7 of the 12 sera protected. Thus, the incidence of protective substances during the acute stage of the disease in the paralytic group was lower than that in the normal urban residents, while in the non-paralytic group it was approximately the same.

\section{Protection tests with sera secured during the first} 9 months of convalescence

Repeated tests were carried out upon the sera of 44 paralytic, 13 non-paralytic and 2 encephalitic patients at various intervals from two weeks to nine months after the onset of the disease. The sera of a few of these individuals had protected in the first week of their illness, but the majority had failed to do so.

\section{Protection tests with convalescent sera from in- dividuals whose sera failed to protect in the first week of the disease}

The following three experiments are typical of the results obtained. 
Experiment 4. The sera of 2 paralytic cases obtained 6 weeks and 4 months, respectively, after the onset were tested together with those obtained in the acute stage of the disease. Similar tests were carried out with specimens of serum from a non-paralytic case and also with specimens obtained from an encephalitic case 3 child, G. C., specimens obtained in the 1st, 3d, and 12th weeks were tested against graded dilutions of virus $(1: 10$ to $1: 80)$. At the same time specimens from 15 paralytics and nonparalytics obtained 1 to 8 months after the onset were tested in the usual way against $1: 10$ and $1: 2$ dilutions of 5 per cent virus. From 3 of

TABLE V

Neutralization tests with convalescent sera of individuals whose sera failed to neutralize in the first week

\begin{tabular}{|c|c|c|c|c|c|c|c|c|}
\hline Patient's initials & Age & Type of case & $\begin{array}{l}\text { Time } \\
\text { after } \\
\text { onset }\end{array}$ & $\begin{array}{l}\text { Dilu- } \\
\text { tion of } \\
5 \text { per } \\
\text { cent } \\
\text { virus }\end{array}$ & $\begin{array}{c}\text { Amount } \\
\text { of } \\
\text { virus }\end{array}$ & $\begin{array}{c}\text { Amount } \\
\text { of } \\
\text { serum }\end{array}$ & $\begin{array}{c}\text { Number } \\
\text { of } \\
\text { monkey }\end{array}$ & Results \\
\hline Negative control. & \multicolumn{3}{|c|}{ Normal monkey serum } & $1: 10$ & $\begin{array}{ll}c c . \\
0.13\end{array}$ & $\begin{array}{l}c c . \\
0.60\end{array}$ & $\mathrm{~J} 75$ & Paralyzed 8 days \\
\hline Negative control.......... & \multicolumn{3}{|c|}{ Normal monkey serum } & $1: 5$ & 0.13 & 0.60 & $\mathrm{~J} 63$ & Paralyzed 6 days \\
\hline Negative control......... & \multicolumn{3}{|c|}{ Normal monkey serum } & $1: 2$ & 0.13 & 0.60 & J 66 & Paralyzed 8 days \\
\hline Positive control......... & \multicolumn{3}{|c|}{ Normal adult human serum (M.B.) } & $1: 10$ & 0.13 & 0.60 & $\mathrm{~J} 64$ & No paralysis \\
\hline Positive control. & \multicolumn{3}{|c|}{ Normal adult human serum (M.B.) } & $1: 5$ & 0.13 & 0.60 & J 74 & No paralysis \\
\hline Positive control. . & \multicolumn{3}{|c|}{ Normal adult human serum (M.B.) } & $1: 2$ & 0.13 & 0.60 & 145 & No paralysis \\
\hline 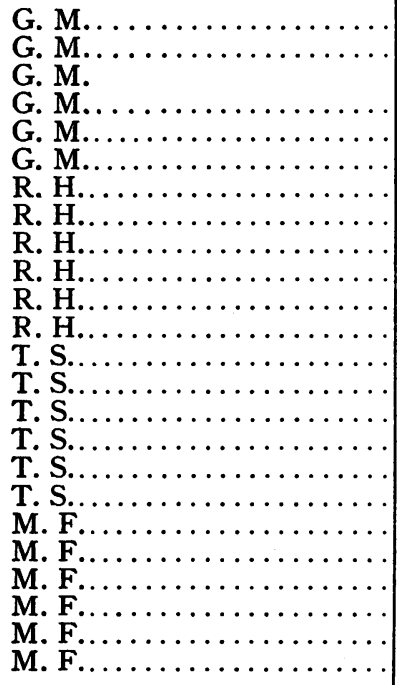 & $\begin{array}{r}13 \\
13 \\
13 \\
13 \\
13 \\
13 \\
6 \\
6 \\
6 \\
6 \\
6 \\
6 \\
6 \\
6 \\
6 \\
6 \\
6 \\
6 \\
7 \\
7 \\
7 \\
7 \\
7 \\
7\end{array}$ & $\begin{array}{l}\text { Paralytic } \\
\text { Paralytic } \\
\text { Paralytic } \\
\text { Paralytic } \\
\text { Paralytic } \\
\text { Paralytic } \\
\text { Paralytic } \\
\text { Paralytic } \\
\text { Paralytic } \\
\text { Paralytic } \\
\text { Paralytic } \\
\text { Paralytic } \\
\text { Non-paralytic } \\
\text { Non-paralytic } \\
\text { Non-paralytic } \\
\text { Non-paralytic } \\
\text { Non-paralytic } \\
\text { Non-paralytic } \\
\text { Encephalitic } \\
\text { Encephalitic } \\
\text { Encephalitic } \\
\text { Encephalitic } \\
\text { Encephalitic } \\
\text { Encephalitic }\end{array}$ & \begin{tabular}{|l|}
2 days \\
2 days \\
2 days \\
4 months \\
4 months \\
4 months \\
2 days \\
2 days \\
2 days \\
6 weeks \\
6 weeks \\
6 weeks \\
3 days \\
3 days \\
3 days \\
3 weeks \\
3 weeks \\
3 weeks \\
19 days \\
19 days \\
19 days \\
5 months \\
5 months \\
5 months
\end{tabular} & $\begin{array}{ll}1 & : 10 \\
1 & : 5 \\
1 & : 2 \\
1 & : 10 \\
1 & : 5 \\
1 & : 2 \\
1 & : 10 \\
1 & : 5 \\
1 & : 2 \\
1 & : 10 \\
1 & : 5 \\
1 & : 2 \\
1 & : 10 \\
1 & : 5 \\
1 & : 2 \\
1 & : 10 \\
1 & : 5 \\
1 & : 2 \\
1 & : 10 \\
1 & : 5 \\
1 & : 2 \\
1 & : 10 \\
1 & : 5 \\
1 & : 2\end{array}$ & $\begin{array}{l}0.13 \\
0.13 \\
0.13 \\
0.13 \\
0.13 \\
0.13 \\
0.13 \\
0.13 \\
0.13 \\
0.13 \\
0.13 \\
0.13 \\
0.13 \\
0.13 \\
0.13 \\
0.13 \\
0.13 \\
0.13 \\
0.13 \\
0.13 \\
0.13 \\
0.13 \\
0.13 \\
0.13\end{array}$ & $\begin{array}{l}0.60 \\
0.60 \\
0.60 \\
0.60 \\
0.60 \\
0.60 \\
0.60 \\
0.60 \\
0.60 \\
0.60 \\
0.60 \\
0.60 \\
0.60 \\
0.60 \\
0.60 \\
0.60 \\
0.60 \\
0.60 \\
0.60 \\
0.60 \\
0.60 \\
0.60 \\
0.60 \\
0.60\end{array}$ & $\begin{array}{ll}\mathrm{J} & 79 \\
\mathrm{~J} & 88 \\
& 226 \\
\mathrm{~J} & 87 \\
\mathrm{~J} & 84 \\
\mathrm{~J} & 56 \\
\mathrm{~J} & 83 \\
\mathrm{~J} & 77 \\
\mathrm{~J} & 28 \\
\mathrm{~J} & 85 \\
\mathrm{~J} & 81 \\
\mathrm{~J} & 1 \\
\mathrm{~J} & 80 \\
\mathrm{~J} & 76 \\
\mathrm{~J} & 57 \\
\mathrm{~J} & 69 \\
\mathrm{~J} & 78 \\
& 211 \\
\mathrm{~J} & 65 \\
\mathrm{~J} & 67 \\
\mathrm{~J} & 32 \\
\mathrm{~J} & 89 \\
\mathrm{~J} & 86 \\
\mathrm{~J} & 18\end{array}$ & $\begin{array}{ll}\text { Paralyzed } & 6 \text { days } \\
\text { Prostrate } 6 \text { days } \\
\text { Paralyzed } 8 \text { days } \\
\text { Paralyzed } 7 \text { days } \\
\text { Paralyzed } 7 \text { days } \\
\text { Paralyzed } 7 \text { days } \\
\text { Paralyzed } 9 \text { days } \\
\text { Paralyzed } 5 \text { days } \\
\text { Paralyzed } 7 \text { days } \\
\text { Paralyzed } 6 \text { days } \\
\text { Paralyzed } 9 \text { days } \\
\text { Paralyzed } 9 \text { days } \\
\text { Paralyzed } 6 \text { days } \\
\text { Paralyzed } 8 \text { days } \\
\text { Paralyzed } 6 \text { days } \\
\text { Paralyzed } 12 \text { days } \\
\text { Paralyzed } 7 \text { days } \\
\text { Paralyzed } 6 \text { days } \\
\text { Paralyzed } 7 \text { days } \\
\text { Paralyzed } 12 \text { days } \\
\text { Paralyzed } 7 \text { days } \\
\text { Prostrate } 6 \text { days } \\
\text { Paralyzed } 8 \text { days } \\
\text { Paralyzed } 6 \text { days }\end{array}$ \\
\hline
\end{tabular}

weeks and 5 months, respectively, after the onset. Each serum was tested with three different dilutions of virus. The results of these tests (Table V) failed to show any evidence that protective substances had developed in these four convalescent sera.

Experiment 5. To determine whether any evidence whatsoever of protective power could be detected in convalescent sera from a paralytic these individuals, the specimens collected during the first week and 3 subsequent specimens were tested. The results (Table VI) of this experiment agreed with those of the previous one, in that none of the 12 sera from paralytics had shown protective power when tested from 2 to 8 months after the onset. Likewise, the 3 sera from non-paralytics failed to neutralize the virus. Unfortunately, the positive control serum failed 
TABLE VI

Neutralization tests with convalescent sera from individuals whose sera failed to neutralize in the first week

\begin{tabular}{|c|c|c|c|c|c|c|c|c|}
\hline Patient's initials & Age & Type of case & $\begin{array}{l}\text { Time } \\
\text { after } \\
\text { onset }\end{array}$ & $\begin{array}{l}\text { Dilu- } \\
\text { tion of } \\
5 \text { per } \\
\text { cent } \\
\text { virus }\end{array}$ & $\begin{array}{c}\text { Amount } \\
\text { of } \\
\text { virus }\end{array}$ & $\begin{array}{c}\text { Amount } \\
\text { of } \\
\text { serum }\end{array}$ & $\begin{array}{c}\text { Number } \\
\text { of } \\
\text { monkey }\end{array}$ & Results \\
\hline Negative control . & \multicolumn{3}{|c|}{ Normal monkey serum } & $1: 2$ & $\begin{array}{c}c c . \\
0.13\end{array}$ & $\begin{array}{ll}c c . \\
0.60\end{array}$ & J 197 & Paralyzed 6 days \\
\hline Negative control & \multicolumn{3}{|c|}{ Normal monkey serum } & $1: 10$ & 0.13 & 0.60 & J 199 & Paralyzed 8 days \\
\hline Negative control & \multicolumn{3}{|c|}{ Normal monkey serum } & $1: 20$ & 0.13 & 0.60 & J 198 & Paralyzed 6 days \\
\hline Negative control & \multicolumn{3}{|c|}{ Normal monkey serum } & $1: 40$ & 0.13 & 0.60 & J 196 & Paralyzed 7 days \\
\hline Negative control & \multicolumn{3}{|c|}{ Normal monkey serum } & $1: 80$ & 0.13 & 0.60 & J 194 & Paralyzed 6 days \\
\hline Positive control. & \multicolumn{3}{|c|}{ Normal adult human serum (M.B.) } & * & 0.20 & 0.45 & J 178 & Paralyzed 15 days \\
\hline Positive control. . & \multicolumn{3}{|c|}{ Normal adult human serum (M.B.) } & * & 0.45 & 0.45 & J 64 & Partial paralysis 15 days \\
\hline Positive control. . & \multicolumn{3}{|c|}{ Normal adult human serum (M.B.) } & * & 0.45 & $0.45 \ddagger$ & $\mathrm{J} 74$ & Paralyzed 10 days \\
\hline 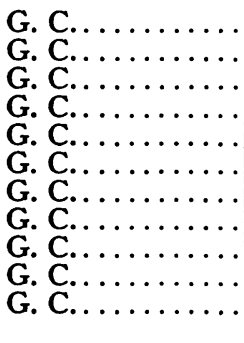 & $\begin{array}{l}5 \\
5 \\
5 \\
5 \\
5 \\
5 \\
5 \\
5 \\
5 \\
5 \\
5\end{array}$ & $\begin{array}{l}\text { Paralytic } \\
\text { Paralytic } \\
\text { Paralytic } \\
\text { Paralytic } \\
\text { Paralytic } \\
\text { Paralytic } \\
\text { Paralytic } \\
\text { Paralytic } \\
\text { Paralytic } \\
\text { Paralytic } \\
\text { Paralytic }\end{array}$ & \begin{tabular}{|c|}
5 days \\
5 days \\
5 days \\
19 days \\
19 days \\
19 days \\
19 days \\
3 months \\
3 months \\
3 months \\
3 months
\end{tabular} & 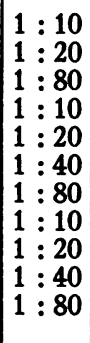 & $\begin{array}{l}0.13 \\
0.13 \\
0.13 \\
0.13 \\
0.13 \\
0.13 \\
0.13 \\
0.13 \\
0.13 \\
0.13 \\
0.13\end{array}$ & $\begin{array}{l}0.60 \\
0.60 \\
0.60 \\
0.60 \\
0.60 \\
0.60 \\
0.60 \\
0.60 \\
0.60 \\
0.60 \\
0.60\end{array}$ & $\begin{array}{ll}\mathrm{J} & 186 \\
\mathrm{~J} & 187 \\
\mathrm{~J} & 185 \\
\mathrm{~J} & 191 \\
\mathrm{~J} & 190 \\
\mathrm{~J} & 189 \\
\mathrm{~J} & 188 \\
\mathrm{~J} & 192 \\
\mathrm{~J} & 193 \\
\mathrm{~J} & 175 \\
\text { B.U. }\end{array}$ & $\begin{array}{l}\text { Paralyzed } 7 \text { days } \\
\text { Paralyzed } 7 \text { days } \\
\text { Paralyzed } 9 \text { days } \\
\text { Paralyzed } 7 \text { days } \\
\text { Paralyzed } 36 \text { days } \\
\text { Paralyzed } 9 \text { days } \\
\text { Paralyzed } 8 \text { days } \\
\text { Paralyzed } 7 \text { days } \\
\text { Paralyzed } 9 \text { days } \\
\text { Paralyzed } 14 \text { days } \\
\text { Died 8th day-Intercurrent in- } \\
\text { fection }\end{array}$ \\
\hline 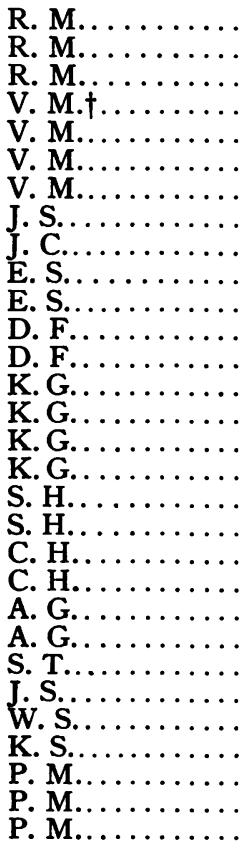 & $\begin{array}{r}4 \\
4 \\
4 \\
4 \\
4 \\
4 \\
4 \\
3 \\
8 \\
5 \\
5 \\
17 \\
17 \\
31 \\
31 \\
31 \\
31 \\
3 \\
3 \\
6 \\
6 \\
29 \\
29 \\
8 \\
5 \\
11 \\
11 \\
3 \\
3 \\
3\end{array}$ & $\begin{array}{l}\text { Paralytic } \\
\text { Paralytic } \\
\text { Paralytic } \\
\text { Paralytic } \\
\text { Paralytic } \\
\text { Paralytic } \\
\text { Paralytic } \\
\text { Paralytic } \\
\text { Paralytic } \\
\text { Paralytic } \\
\text { Paralytic } \\
\text { Paralytic } \\
\text { Paralytic } \\
\text { Paralytic } \\
\text { Paralytic } \\
\text { Paralytic } \\
\text { Paralytic } \\
\text { Paralytic } \\
\text { Paralytic } \\
\text { Paralytic } \\
\text { Paralytic } \\
\text { Paralytic } \\
\text { Paralytic } \\
\text { Paralytic } \\
\text { Non-paralytic } \\
\text { Non-paralytic } \\
\text { Non-paralytic } \\
\text { Non-paralytic } \\
\text { Non-paralytic } \\
\text { Non-paralytic }\end{array}$ & $\begin{array}{l}15 \text { days } \\
26 \text { days } \\
3 \frac{1}{2} \text { months } \\
2 \text { days } \\
19 \text { days } \\
4 \text { months } \\
7 \text { months } \\
8 \text { months } \\
8 \text { months } \\
2 \text { months } \\
6 \text { months } \\
7 \text { weeks } \\
7 \frac{1}{2} \text { months } \\
3 \text { months } \\
3 \text { months } \\
8 \text { months } \\
8 \text { months } \\
6 \text { months } \\
8 \frac{1}{2} \text { months } \\
1 \text { month } \\
7 \text { months } \\
3 \text { weeks } \\
7 \text { months } \\
7 \text { months } \\
6 \text { months } \\
6 \text { months } \\
7 \text { months } \\
3 \text { weeks } \\
3 \text { months } \\
6 \text { months }\end{array}$ & $\begin{array}{ll}1 & : 10 \\
1 & : 10 \\
1 & : 10 \\
1 & : 10 \\
1 & : 10 \\
1 & : 10 \\
1 & : 10 \\
1 & : 10 \\
1 & : 10 \\
1 & : 2 \\
1 & : 2 \\
1 & : 2 \\
1 & : 2 \\
1 & : 2 \\
* \\
1: 2 \\
* \\
1: 10 \\
1: 2 \\
1: 2 \\
1: 2 \\
1: 2 \\
1: 2 \\
1: 2 \\
1: 10 \\
1: 10 \\
1: 10 \\
1: 10 \\
1: 10 \\
1: 10\end{array}$ & $\begin{array}{l}0.13 \\
0.13 \\
0.13 \\
0.13 \\
0.13 \\
0.13 \\
0.13 \\
0.13 \\
0.13 \\
0.13 \\
0.13 \\
0.13 \\
0.13 \\
0.13 \\
0.10 \\
0.13 \\
0.10 \\
0.13 \\
0.13 \\
0.13 \\
0.13 \\
0.13 \\
0.13 \\
0.13 \\
0.13 \\
0.13 \\
0.13 \\
0.13 \\
0.13 \\
0.13\end{array}$ & $\begin{array}{l}0.60 \\
0.60 \\
0.60 \\
0.60 \\
0.60 \\
0.60 \\
0.60 \\
0.60 \\
0.60 \\
0.60 \\
0.60 \\
0.60 \\
0.60 \\
0.60 \\
0.60 \\
0.60 \\
0.60 \\
0.60 \\
0.60 \\
0.60 \\
0.60 \\
0.60 \\
0.60 \\
0.60 \\
0.60 \\
0.60 \\
0.60 \\
0.60 \\
0.60 \\
0.60\end{array}$ & $\begin{array}{ll}\text { J } & 170 \\
\mathrm{~J} & 164 \\
\mathrm{~J} & 163 \\
\mathrm{~J} & 173 \\
\mathrm{~J} & 174 \\
\mathrm{~J} & 168 \\
\mathrm{~J} & 167 \\
\mathrm{~J} & 171 \\
\mathrm{~J} & 172 \\
\mathrm{~N} & 12 \\
\mathrm{~J} & 158 \\
\mathrm{~J} & 182 \\
\mathrm{~J} & 2 \\
\mathrm{~J} & 156 \\
\mathrm{R} & 68 \\
\mathrm{~J} & 155 \\
& 135 \\
\mathrm{~J} & 160 \\
\mathrm{R} & 49 \\
& 498 \\
\mathrm{~J} & 159 \\
\mathrm{R} & 62 \\
\mathrm{~J} & 157 \\
\mathrm{~J} & 176 \\
\mathrm{~J} & 1658 \\
\mathrm{~J} & 166 \\
\mathrm{~J} & 177 \\
\mathrm{~J} & 180 \\
\mathrm{~J} & 181 \\
\mathrm{~J} & 183\end{array}$ & $\begin{array}{l}\text { Paralyzed } 9 \text { days } \\
\text { Paralyzed } 7 \text { days } \\
\text { Paralyzed } 4 \text { days } \\
\text { Paralyzed } 7 \text { days } \\
\text { Paralyzed } 7 \text { days } \\
\text { Paralyzed } 6 \text { days } \\
\text { Paralyzed } 6 \text { days } \\
\text { Paralyzed } 7 \text { days } \\
\text { Paralyzed } 7 \text { days } \\
\text { Paralyzed } 11 \text { days } \\
\text { Paralyzed } 7 \text { days } \\
\text { Paralyzed } 6 \text { days } \\
\text { Paralyzed } 9 \text { days } \\
\text { Paralyzed } 8 \text { days } \\
\text { Paralyzed } 6 \text { days } \\
\text { Paralyzed } 7 \text { days } \\
\text { Paralyzed } 11 \text { days } \\
\text { Paralyzed } 8 \text { days } \\
\text { Paralyzed } 8 \text { days } \\
\text { No paralysis } \\
\text { Paralyzed } 15 \text { days } \\
\text { Paralyzed } 8 \text { days } \\
\text { Paralyzed } 5 \text { days } \\
\text { Paralyzed } 9 \text { days } \\
\text { No paralysis } \\
\text { Paralyzed } 6 \text { days } \\
\text { Paralyzed } 15 \text { days } \\
\text { Paralyzed } 7 \text { days } \\
\text { Paralyzed } 7 \text { days } \\
\text { Paralyzed } 7 \text { days }\end{array}$ \\
\hline
\end{tabular}

* Undiluted.

+ Bulbar case.

$\ddagger 1$ : 6 dilution of serum.

These animals were subsequently proven to be resistant to poliomyelitis virus. The results have been omitted in the tabulations. 
to neutralize $0.2 \mathrm{cc}$. of a 5 per cent virus suspension, an amount of the same batch of virus that this serum had neutralized in Experiment 1; the injected animal contracted poliomyelitis after a prolonged incubation period. In several other experiments, this serum had neutralized $0.13 \mathrm{cc}$. of a 1:2 dilution of a 5 per cent suspension, the usual test dose. In the next experiment, the same serum neutralized a similar test dose of the same batch of virus.

Experiment 6. Inasmuch as the positive control serum in Experiment 5 failed to neutralize the virus, the same positive and negative control that the positive control serum in the previous experiment was tested against too large a dose of virus.

Summary of all tests within the first year with the convalescent sera of individuals whose sera failed to protect in the first week of the disease

A. Paralytics. Convalescent sera from 39 persons of various ages (Table VIII) were tested at frequent intervals after the onset of the disease.

At 2 or 3 weeks after the onset, only 1 of 24

TABLE VII

Recheck of part of Experiment 5

\begin{tabular}{|c|c|c|c|c|c|c|c|c|}
\hline Patient's initials & Age & Type of case & $\begin{array}{l}\text { Time } \\
\text { after } \\
\text { onset }\end{array}$ & $\begin{array}{c}\text { Dilu- } \\
\text { tion of } \\
5 \text { per } \\
\text { cent } \\
\text { virus }\end{array}$ & $\begin{array}{c}\text { Amount } \\
\text { of } \\
\text { virus }\end{array}$ & $\begin{array}{c}\text { Amount } \\
\text { of } \\
\text { serum }\end{array}$ & $\begin{array}{c}\text { Number } \\
\text { of } \\
\text { monkey }\end{array}$ & Results \\
\hline Negative control. & \multicolumn{3}{|c|}{ Normal mor } & $1: 20$ & $\begin{array}{c}c c . \\
0.13\end{array}$ & $\begin{array}{c}c c . \\
0.60\end{array}$ & $\mathrm{~J} 260$ & Paralyzed 7 days \\
\hline Negative control. & \multicolumn{3}{|l|}{ Saline } & $1: 20$ & 0.13 & 0.60 & J 274 & Paralyzed 8 days \\
\hline Positive control. & \multicolumn{3}{|c|}{ Normal adult human serum (M.B.) } & $1: 2$ & 0.13 & 0.60 & $\mathrm{~J} 215$ & No paralysis \\
\hline $\begin{array}{l}\text { A. P..... } \\
\text { V. M.†. } \\
\text { V. M.... } \\
\text { P. M.... }\end{array}$ & $\begin{array}{r}16 \\
4 \\
4 \\
3\end{array}$ & $\begin{array}{l}\text { Non-paralytic } \\
\text { Paralytic } \\
\text { Paralytic } \\
\text { Non-paralytic }\end{array}$ & \begin{tabular}{|l|}
2 days \\
3 days \\
7 months \\
3 months
\end{tabular} & $\begin{array}{c}* \\
1: 20 \\
1: 20 \\
1: 20\end{array}$ & $\begin{array}{l}0.45 \\
0.13 \\
0.13 \\
0.13\end{array}$ & $\begin{array}{l}0.45 \\
0.60 \\
0.60 \\
0.60\end{array}$ & $\begin{array}{l}\text { J } 211 \\
\text { J } 273 \\
\text { J } 277 \\
\text { J } 272\end{array}$ & $\begin{array}{l}\text { No paralysis } \\
\text { Paralyzed } 9 \text { days } \\
\text { Paralyzed } 8 \text { days } \\
\text { Paralyzed } 9 \text { days }\end{array}$ \\
\hline
\end{tabular}

* Undiluted

$\dagger$ Bulbar case.

sera were retested. Whereas, in the previous experiment this positive control serum was tested against 0.2 cc. of a 5 per cent virus suspension, now 0.13 cc. of a $1: 2$ dilution of a 5 per cent suspension of the same batch of virus was used. As another positive control, the serum of a nonparalytic case (A. P.) which had previously protected was tested against a larger dose, $0.45 \mathrm{cc}$. of a 5 per cent virus suspension. In addition, 3 sera (V. M., 2 specimens, and P. M.) which had failed to protect were again tested with smaller amounts of virus than were used in the previous experiment. The results are shown in Table VII.

The positive control serum protected against the usual test dose of virus, while the negative control and the 3 other negative sera which were retested with smaller amounts of virus failed to do so. The serum from the non-paralytic case (A. P.) again protected. It appears, therefore, sera protected; 7 of them were tested both at 2 and 3 weeks. Sera of 18 of the above individuals as well as of 12 others that failed to protect upon admission were retested once or twice at intervals of 1 to 6 months after the onset. Protection occurred in only 2 of these specimens, one, K. F., at 7 weeks, and the other, V. C., at $2 \frac{1}{2}$ and $3 \frac{1}{2}$ months. The latter showed protective substances for the first time on the 16th day.

At 7 to 9 months after the onset 20 of 21 sera tested failed to protect. The one serum that protected was obtained 9 months after the onset of the illness from K. F. who already had shown protective substance at 7 weeks. The other patient whose serum had developed protective substance previously was not available for retesting. The sera from 18 of the 21 individuals had been tested earlier during convalescence; 4 once, 12 two or three times and 2 , four times always with 
TABLE VIII

Summary of neutralization tests during first year of convalescence of individuals whose sera failed to neutralize in the first week

\begin{tabular}{|c|c|c|c|c|}
\hline \multirow{2}{*}{ Age groups } & \multicolumn{2}{|c|}{ Paralytic } & \multicolumn{2}{|c|}{ Non-paralytic } \\
\hline & $\begin{array}{c}\text { Number } \\
\text { tested }\end{array}$ & $\underset{\text { neutralized }}{\text { Number }}$ & $\begin{array}{c}\text { Number } \\
\text { tested }\end{array}$ & $\begin{array}{c}\text { Number } \\
\text { neutralized }\end{array}$ \\
\hline $\begin{array}{c}\text { years } \\
1-5 \ldots \ldots \ldots \\
6-10 \ldots \ldots \cdots \\
11-17 \ldots \ldots \cdots \\
\text { Adult } \ldots \ldots \ldots \ldots\end{array}$ & $\begin{array}{r}16 \\
14 \\
6 \\
3\end{array}$ & $\begin{array}{l}1 \\
0 \\
1 \\
0\end{array}$ & $\begin{array}{l}2 \\
6 \\
3 \\
0\end{array}$ & $\begin{array}{l}0 \\
0 \\
0 \\
0\end{array}$ \\
\hline Total. & 39 & 2 & 11 & 0 \\
\hline
\end{tabular}

negative results. The other 3 had been tested previously only in the acute stage of the disease.

$B$. Non-paralytics. Convalescent sera from 11 persons of various ages were tested at frequent intervals after the onset of the disease (Table VIII). Seven sera were tested 2 to 3 weeks after the onset and none neutralized the virus. Six sera, tested 1 to 3 months after the onset, showed no protective power; three of them had been tested previously during convalescence. Six sera tested 6 to 7 months after the onset also gave negative results; all but one of these had been tested earlier in convalescence.

C. Cases with encephalitic symptoms. The sera from two of these patients were tested and failed to show protective substances; one of them was tested 3 and 7 weeks, and 3 and 5 months after the onset, the other $61 / 2$ months after the onset.

\section{Summary of tests with convalescent sera from individuals whose sera protected in the first week of the disease}

The sera of 5 paralytics and 2 non-paralytics which showed protective power in the acute stage, when retested at later intervals still protected. The sera from two of the paralytics were retested in the second and third week respectively; two others at the end of 2 months; and the fifth after 6 months. One of the non-paralytics whose sera had protected on the 5th day, gave similar results in the $2 \mathrm{~d}$ and 4 th weeks, the other which had protected on the 4th day, also protected 6 months later. Thus, the ability of a serum to protect in the acute stage of the disease did not appear to be temporary, but was main- tained for some time at least. However, no evidence of an increase in protective power was demonstrated either in two paralytics or in one non-paralytic. Serum from one of the paralytics had neutralized 0.1 cc. of a 5 per cent virus suspension in the acute stage, but failed to neutralize 0.2 cc. after 3 months. The other did not neutralize $0.1 \mathrm{cc}$. of a 5 per cent virus after 7 weeks, although a specimen obtained during the first week neutralized half that amount. A nonparalytic case also failed to show an increase of protective antibodies after $61 / 2$ months.

\section{Tests with a strain of virus isolated in 1935}

In order to compare the results with those obtained previously with the passage virus, two experiments were performed upon sera obtained in the acute and convalescent stages using the strain isolated from nasal washings.

Experiment 7. Ten specimens from $7 \mathrm{pa}-$ tients were tested; 3 were taken both in the acute and convalescent stages and 4 only in convalescence. None of these specimens had neutralized the $\mathrm{F} 1$ virus. The results, shown in Table IX, indicated that 2 of the 3 sera obtained soon after the onset and all of the 7 convalescent specimens failed to protect.

Experiment 8. Sixteen sera were tested. Six of these had previously protected against the passage virus. These included 3 specimens obtained from non-paralytics in the acute stage and 3 from paralytics during convalescence. Two of the latter (V. C. and K. F.) were from patients who showed protective substances both in the acute stage and in convalescence. Nine specimens obtained 5 to 9 months after the onset had failed to neutralize the F1 strain. Two of these were from non-paralytics and 7 from paralytics. The 16 th serum was an acute-stage specimen of S. S. which appeared to protect against the recently isolated strain in Experiment 7 but had failed to neutralize the passage virus previously. The results are given in Table $\mathrm{X}$. All 6 specimens which had protected against the passage virus also neutralized the recently isolated strain. The 9 convalescent sera which had failed to protect against the passage virus also failed to protect when the recently isolated strain was used. The specimen obtained from S. S. in the acute stage, 
TABLE IX

Neutralization tests with a strain of virus isolated during the 1935 outbreak

\begin{tabular}{|c|c|c|c|c|c|c|c|c|}
\hline Patient's initials & Age & Type of case & $\begin{array}{l}\text { Time } \\
\text { after } \\
\text { onset }\end{array}$ & $\begin{array}{c}\text { Dilu- } \\
\text { tion of } \\
5 \text { per } \\
\text { cent } \\
\text { virus }\end{array}$ & $\begin{array}{c}\text { Amount } \\
\text { of } \\
\text { virus }\end{array}$ & $\begin{array}{c}\text { Amount } \\
\text { of } \\
\text { serum }\end{array}$ & $\begin{array}{c}\text { Number } \\
\text { of } \\
\text { monkey }\end{array}$ & Results \\
\hline Negative control... & \multicolumn{3}{|c|}{ Normal monkey serum } & $1: 2$ & $\begin{array}{c}c c . \\
0.13\end{array}$ & $\begin{array}{c}c c . \\
0.60\end{array}$ & J 252 & No paralysis \\
\hline Negative control.......... & \multicolumn{3}{|c|}{ Normal monkey serum } & $1: 10$ & 0.13 & 0.60 & $\mathrm{~J} 253$ & Paralyzed 14 days \\
\hline Negative control. . & \multicolumn{3}{|c|}{ Normal monkey serum } & $1: 40$ & 0.13 & 0.60 & J 248 & Paralyzed 8 days \\
\hline Positive control.......... & \multicolumn{3}{|c|}{ Normal adult human serum (A.G.) } & $1: 2$ & 0.13 & 0.60 & $\mathrm{~J} 72$ & No paralysis \\
\hline 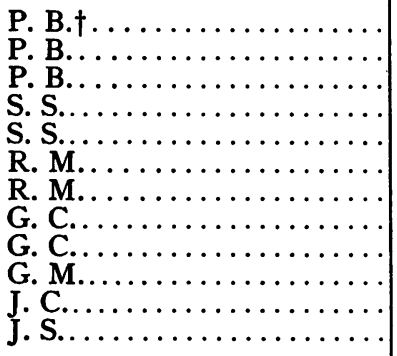 & $\begin{array}{r}5 \\
5 \\
5 \\
9 \\
9 \\
4 \\
4 \\
5 \\
5 \\
13 \\
8 \\
3\end{array}$ & $\begin{array}{l}\text { Paralytic } \\
\text { Paralytic } \\
\text { Paralytic } \\
\text { Paralytic } \\
\text { Paralytic } \\
\text { Paralytic } \\
\text { Paralytic } \\
\text { Paralytic } \\
\text { Paralytic } \\
\text { Paralytic } \\
\text { Paralytic } \\
\text { Paralytic }\end{array}$ & $\begin{array}{l}3 \text { days } \\
4 \text { months } \\
4 \text { months } \\
5 \text { days } \\
7 \text { months } \\
5 \text { days } \\
3 \frac{1}{2} \text { months } \\
3 \text { months } \\
3 \text { months } \\
4 \text { months } \\
7 \text { months } \\
8 \text { months }\end{array}$ & $\begin{array}{ll}1 & : 10 \\
1 & : 2 \\
1 & : 10 \\
1 & : 10 \\
1 & : 10 \\
1 & : 2 \\
1 & : 2 \\
1 & : 2 \\
1 & : 10 \\
1 & : 2 \\
1 & : 10 \\
1 & : 10\end{array}$ & $\begin{array}{l}0.13 \\
0.13 \\
0.13 \\
0.13 \\
0.13 \\
0.13 \\
0.13 \\
0.13 \\
0.13 \\
0.13 \\
0.13 \\
0.13\end{array}$ & $\begin{array}{l}0.60 \\
0.60 \\
0.60 \\
0.60 \\
0.60 \\
0.60 \\
0.60 \\
0.60 \\
0.60 \\
0.60 \\
0.60 \\
0.60\end{array}$ & $\begin{array}{ll}\mathrm{J} & 249 \\
\mathrm{~J} & 73 \\
\mathrm{~J} & 241 \\
\mathrm{~J} & 244 \\
\mathrm{~J} & 243 \\
\mathrm{~J} & 258 \\
\mathrm{~J} & 257 \\
555 \\
\mathrm{~J} & 242 \\
\mathrm{~J} & 259 \\
\mathrm{~J} & 246 \\
\mathrm{~J} & 247\end{array}$ & $\begin{array}{l}\text { Paralyzed } 6 \text { days } \\
\text { Paralyzed } 15 \text { days } \\
\text { Paralyzed } 8 \text { days } \\
\text { No paralysis } \\
\text { Paralyzed } 8 \text { days } \\
\text { Paralyzed } 5 \text { days } \\
\text { Paralyzed } 6 \text { days } \\
\text { Paralyzed } 13 \text { days } \\
\text { Paralyzed } 8 \text { days } \\
\text { Paralyzed } 6 \text { days } \\
\text { Paralyzed } 8 \text { days } \\
\text { Paralyzed } 12 \text { days }\end{array}$ \\
\hline
\end{tabular}

† Bulbar case.

TABLE $X$

Neutralization tests with a strain of virus isolated during the 1935 outbreak

\begin{tabular}{|c|c|c|c|c|c|c|c|c|}
\hline Patient's initials & Age & $\begin{array}{c}\text { Type of case } \\
.\end{array}$ & $\begin{array}{l}\text { Time } \\
\text { after } \\
\text { onset }\end{array}$ & $\begin{array}{c}\text { Dilu- } \\
\text { tion of } \\
5 \text { per } \\
\text { cent } \\
\text { virus }\end{array}$ & $\begin{array}{c}\text { Amount } \\
\text { of } \\
\text { virus }\end{array}$ & $\begin{array}{l}\text { Amount } \\
\text { of } \\
\text { serum }\end{array}$ & $\begin{array}{c}\text { Number } \\
\text { of } \\
\text { monkey }\end{array}$ & Results \\
\hline Negative control... & \multicolumn{3}{|c|}{ Normal monkey serum } & $1: 10$ & $\begin{array}{c}c c . \\
0.13\end{array}$ & $\begin{array}{c}c c . \\
0.60\end{array}$ & J 250 & Paralyzed 8 days \\
\hline Negative control. & \multicolumn{3}{|c|}{ Normal monkey serum } & $1: 10$ & 0.13 & 0.60 & J 271 & Paralyzed 12 days \\
\hline Negative control......... & \multicolumn{3}{|c|}{ Normal monkey serum } & $1: 80$ & 0.13 & 0.60 & J 289 & No paralysis \\
\hline Positive control $\ldots \ldots \ldots \ldots$ & \multicolumn{3}{|c|}{ Normal adult human serum (A.G.) } & $1: 2$ & 0.13 & 0.60 & J 267 & No paralysis \\
\hline 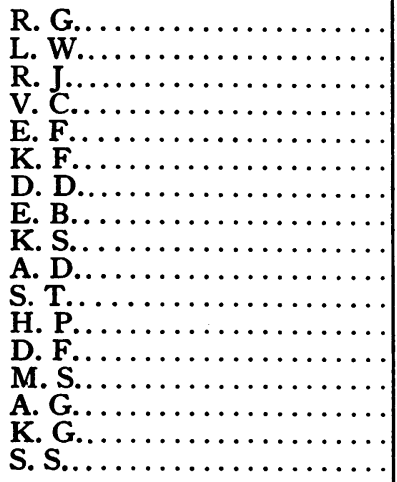 & $\begin{array}{r}3 \\
8 \\
16 \\
2 \\
4 \\
13 \\
8 \\
11 \\
11 \\
2 \\
8 \\
9 \\
17 \\
26 \\
29 \\
31 \\
9\end{array}$ & $\begin{array}{c}\text { Non-paralytic } \\
\text { Non-paralytic } \\
\text { Non-paralytic } \\
\text { Paralytic } \\
\text { Paralytic } \\
\text { Paralytic } \\
\text { Non-paralytic } \\
\text { Non-paralytic } \\
\text { Non-paralytic } \\
\text { Paralytic } \\
\text { Paralytic } \\
\text { Paralytic } \\
\text { Paralytic } \\
\text { Paralytic } \\
\text { Paralytic } \\
\text { Paralytic } \\
\text { Paralytic }\end{array}$ & \begin{tabular}{|}
4 days \\
2 days \\
4 days \\
$3 \frac{1}{2}$ months \\
3 months \\
$8 \frac{1}{2}$ months \\
6 months \\
$5 \frac{1}{2}$ months \\
6 months \\
$8 \frac{1}{2}$ months \\
7 months \\
9 months \\
$7 \frac{1}{2}$ months \\
$7 \frac{1}{2}$ months \\
7 months \\
$7 \frac{1}{2}$ months \\
5 months
\end{tabular} & $\begin{array}{ll}1 & : 2 \\
1 & : 2 \\
1 & : 2 \\
1 & : 2 \\
1 & : 2 \\
1 & : 2 \\
1 & : 2 \\
1 & : 2 \\
1 & : 10 \\
1 & : 10 \\
1 & : 2 \\
1 & : 2 \\
1 & : 2 \\
1 & : 2 \\
1 & : 2 \\
1 & : 2 \\
1 & : 10\end{array}$ & $\begin{array}{l}0.13 \\
0.13 \\
0.13 \\
0.13 \\
0.13 \\
0.13 \\
0.13 \\
0.13 \\
0.13 \\
0.13 \\
0.13 \\
0.13 \\
0.13 \\
0.13 \\
0.13 \\
0.13 \\
0.13\end{array}$ & $\begin{array}{l}0.60 \\
0.60 \\
0.60 \\
0.60 \\
0.60 \\
0.60 \\
0.60 \\
0.60 \\
0.60 \\
0.60 \\
0.60 \\
0.60 \\
0.60 \\
0.60 \\
0.60 \\
0.60 \\
0.60\end{array}$ & $\begin{array}{ll}\mathrm{J} & 215 \\
\mathrm{~J} & 256 \\
\mathrm{~J} & 239 \\
\mathrm{~J} & 290 \\
\mathrm{~J} & 266 \\
\mathrm{~J} & 263 \\
\mathrm{~J} & 165 \\
\mathrm{~J} & 291 \\
\mathrm{~J} & 278 \\
\mathrm{~J} & 284 \\
\mathrm{~J} & 276 \\
\mathrm{~J} & 280 \\
\mathrm{~J} & 264 \\
\mathrm{~J} & 262 \\
\mathrm{~J} & 220 \\
\mathrm{~J} & 275 \\
\mathrm{~J} & 286\end{array}$ & $\begin{array}{l}\text { No paralysis } \\
\text { No paralysis } \\
\text { No paralysis } \\
\text { No paralysis } \\
\text { No paralysis } \\
\text { No paralysis } \\
\text { No paralysis } \\
\text { Paralyzed } 7 \text { days } \\
\text { Paralyzed } 6 \text { days } \\
\text { Paralyzed } 10 \text { days } \\
\text { Paralyzed } 7 \text { days } \\
\text { Paralyzed } 9 \text { days } \\
\text { Paralyzed } 11 \text { days } \\
\text { Paralyzed } 11 \text { days } \\
\text { Paralyzed } 9 \text { days } \\
\text { Paralyzed } 7 \text { days } \\
\text { Paralyzed } 11 \text { days }\end{array}$ \\
\hline
\end{tabular}

† This animal was resistant to poliomyelitis virus. The result was not included in the tabulations. 
now failed to neutralize, a finding in keeping with that obtained with the passage virus.

These two experiments indicated that sera obtained in the acute and convalescent stages reacted similarly to both strains of virus. Three of 6 specimens obtained in the acute stage protected against both strains, and 3 failed to neutralize either strain. Three of 19 specimens obtained several months after the onset protected against both strains, whereas the other 16 neutralized neither strain of virus. The majority of convalescent sera thus failed to protect against a strain of virus obtained from the nasal washings of a patient in the same outbreak.

\section{Neutralization tests in which passage virus and sera obtained from 12 to 16 months after the onset of the disease were used}

Experiment 9. Thirty sera were tested, 24 from paralytic patients, 5 from non-paralytics and 1 from a patient who had the encephalitic form. Specimens taken from these patients during the acute stage and at intervals during the first year of convalescence had failed to neutralize the virus. The sera from two of the paralytic cases and one non-paralytic case taken 12 to 16 weeks after the onset neutralized the virus in duplicate tests. Thus, 3 of 30 patients apparently developed protective substances at the beginning of the second year following the illness. Two other persons whose sera protected during the acute stages of the disease were bled a year later in order to determine whether the neutralizing substances were still present. Both sera again protected.

\section{DISCUSSION}

Protective substances were found in 14 of 82 paralytic individuals in the first week of the disease; several of these patients had extensive paralysis. Kling and Levaditi (6), Flexner and Amoss (7), and Harmon and Harkins (15) also recorded instances in which protective substances were detected in the first week of illness. The first two authors $(6,7)$ thought that the detected neutralizing bodies had developed rapidly after the onset, while Harmon and Harkins (15) believed that they were present prior to infection. We concur with the latter opinion, for protective substances were found very early in the disease and did not develop readily in convalescence. The presence of protective substances were demonstrated in the sera of two patients in the preparalytic stage, in one patient on the day paralysis developed, and in several others as early as one and two days after the onset. In one of the cases tested by Harmon and Harkins (15) neutralizing substance was also found in the preparalytic stage. On the other hand, when 39 of our 68 patients without protective substances in the acute stage were retested during the first year of convalescence, protective substances were found in the sera of only 2. Moreover, the sera of 2 individuals which had neutralizing power in the first week of the illness did not show a demonstrable increase during convalescence. Other observers also found that neutralizing substances did not develop readily during convalescence following paralysis $(15,19)$.

Non-paralytic cases showed protective substances in the acute stage of the disease more frequently (18 out of 32 ) than did paralytic cases. The neutralizing substances probably were present before the onset and did not develop rapidly after the disease set in. Their presence was detected as early as the first and second day of the illness. On the other hand, 11 of the 14 cases whose sera had no protective substances in the acute stage of the disease when retested several months later were still negative. This finding is in agreement with that of Paul and Trask (19) who found no neutralizing substance in a nonparalytic case several weeks and again one year after the onset.

The failure to develop protective substances in convalescent sera from paralytic cases also coincided with the findings of Paul and Trask (19) who showed that 6 of 7 sera taken $11 / 2$ to 10 weeks after the onset failed to neutralize the virus; 2 of them when retested a year later still failed to neutralize. On the other hand, Jensen (24) reported the presence of antibodies in paralytic and non-paralytic cases within a month after the onset. In a recent paper, however, Eagles and coworkers (25) stated that a pooled serum obtained from 67 paralytic patients approximately 4 weeks after the onset failed to neutralize the virus of poliomyelitis.

The failure of the majority of patients to de- 
velop protective substances within 6 to 9 months after the onset is further confirmed by the negative results obtained with a strain of virus isolated from the same outbreak. Such findings differ from those of Howitt (22) who reported that convalescent serum more often neutralized a recently isolated strain than a passage virus. Likewise, Paul and Trask (19) found that convalescent sera from 6 of 7 paralytic cases neutralized a recently isolated strain, whereas only one serum neutralized the passage virus. It is possible that the strain used in the present work was more closely related to the passage virus than that used by the above workers $(19,22)$, for both strains of virus reacted similarly to 25 sera, 6 neutralizing and 19 failing to neutralize each strain. Moreover, 4 of 6 monkeys with residual paralysis that had recovered and were resistant to reinfection with $\mathrm{F} 1$ virus, were resistant also to the other strain. One of the 2 which failed to resist, developed only a mild attack with a rise in temperature and transitory weakness of the arms. On the other hand, the above mentioned investigators may have obtained neutralization more often with their recently isolated strains because they were less virulent than the passage strains. Howitt (22) indicated that the strain she used did not infect with regularity, while Paul and Trask (19) mentioned that their virus usually caused a less severe form of the disease than did the passage virus.

The absence of protective bodies during the first few months of convalescence in 48 of 50 paralytic and non-paralytic individuals whose sera failed to neutralize upon admission was demonstrated not only when $0.13 \mathrm{cc}$. of a 2.5 per cent ( $1: 2$ dilution of a 5 per cent virus suspension) was mixed with $0.6 \mathrm{cc}$. of serum, but also in many instances when tested against much smaller amounts of virus. Even though a number of sera were tested against $0.13 \mathrm{cc}$. of 5 per cent virus diluted 10 to 64 times, and in one instance 80 times, they still failed to neutralize. Smaller amounts of virus were used in testing these sera than most other investigators have employed. However, the intracerebral inoculation of a virus-serum mixture may not be suitable for the demonstration of neutralizing antibodies. Even though diluted virus suspensions were used, the test still may be too severe.

A higher incidence of protective substances, 63 per cent, has been reported (Table I) in convalescent sera from paralytics obtained years after the disease, than was found in the present work in which the sera were collected within a year of onset. Our figure was approximately 22 per cent and included neutralizing substances found at the onset of the disease (17 per cent), and those which developed in convalescence ( 5 per cent). There have been no significantly large number of sera taken by any one group of investigators within one year of the onset of the disease for comparison with the results of the present work. The variations in technique would hardly explain the different results, for other workers frequently obtained neutralization although larger amounts of virus suspension were used. Howitt (20b) reported that pooled convalescent sera from long standing cases had a higher titer of neutralizing substances than those from recently recovered cases. In this investigation, the sera of 24 paralytics which had failed to neutralize during the first 9 months of convalescence, were retested 12 to 16 months after the onset. Two of these specimens obtained 14 months after the onset from children 7 and 9 years of age neutralized for the first time. It is also possible that more of these individuals may subsequently develop neutralizing substances. If this does occur, is it due to the slow development of neutralizing substances, is it produced by further exposure to the virus resulting in hyperimmunization, or can it appear as a result of nonspecific factors as Jungeblut and Engle (26) have suggested? It is noteworthy that the sera which neutralized at the beginning of the second year after the onset were obtained in October 1936. However, there was practically no poliomyelitis in New York City during 1936. The children from whom the sera were obtained had not been in a locality where poliomyelitis was prevalent.

Until recently the presence of neutralizing substances in the serum was accepted as an index of immunity to poliomyelitis. Certain experimental and clinical observations, however, do not support this view. It has been shown $(27,28)$ that sera of monkeys injected subcutaneously with a 
subinfective dose of virus may after a few weeks neutralize poliomyelitis virus in vitro, even though the animals are not able to resist an intracerebral or intranasal instillation of potent virus. Further, convalescent monkeys which are refractory to reinoculation may show no neutralizing substance in their sera $(29,30,31)$. Evidence has been presented previously to support the contention that protective substances were present in 14 of 82 paralytic patients when the disease developed. There was no evidence to indicate that the paralysis was less extensive in the 14 persons whose serum neutralized in the acute stage than in the 68 whose serum failed to do so. Only 2 of the 14 had mild paralysis, that is a partial involvement of one limb, 2 had bulbar involvement, 2 others showed extensive paralysis of one leg. The remaining 8 had involvement of 2 extremities or more. Of the 68 whose serum failed to neutralize in the acute stage, 8 had a mild paralysis, 13 had involvement of one leg and 9 cases were bulbar. The remaining 38 had a muscular paralysis in at least two extremities. The majority of sera tested from the convalescent paralytic patients without protective substances in the first week of the disease did not develop any as late as 12 to 16 months after the onset of the disease. Nevertheless, second attacks of poliomyelitis are rare. Although one cannot always interpret human disease in the light of animal experimentation, one may assume an immunity in the majority of convalescent poliomyelitis patients in the absence of protective substances in the serum.

On the other hand, the incidence of protective substance in non-paralytic patients is greater than that in paralytics and approximates that in normal individuals of the same age. In the acute stage of the disease in non-paralytic patients its presence may help to limit the spread of the virus, while in the paralytics its frequent absence may be a factor accounting for the widespread involvement in some cases. Very noteworthy was the absence of neutralizing substances in the specimens of serum taken on admission and one year later from a paralytic boy who had had a previous attack of poliomyelitis in 1933 with residual paralysis.

Consequently, it appears that there must be factors other than the presence or absence of protective substances in the serum that determine the resistance of the host to poliomyelitis. Indeed, in interpreting these results, we must consider the possibility that the neutralizing substances are not specific, that is, they may develop irrespective of exposure to the virus. The immunity present in the absence of neutralizing substances may be cellular rather than humoral.

The presence or absence of neutralizing substances in the acute and convalescent stages was not related to the degree of recovery from paralysis, a finding in agreement with that of Harmon and Harkins (15). Howitt (12), on the other hand, indicated that some correlation did exist between these two factors. We were unable to find that the 14 paralytic cases who had neutralizing substances in the acute stage improved more rapidly than the other 68 who had none. Indeed, in three of the 14, the paralysis was progressive. Of the two paralytic individuals (Table VIII) who developed demonstrable neutralizing substances within the first 9 months of convalescence, one showed considerable recovery of muscular power in several months, while the other improved slowly although a progressive increase in neutralizing substances was demonstrated after the 16th day. In 16 of 20 whose sera had failed to neutralize after 7 to 9 months, considerable clinical improvement occurred. One bulbar case and two spinal-paralytic cases made a complete recovery within a month after the onset.

The protection test offers no aid in the diagnosis of non-paralytic poliomyelitis. In the acute stage the proportion of sera from patients over the age of 5 that neutralized approximated that for normal individuals. Further, 11 of those whose sera showed no neutralizing power in the acute stage did not develop any within 6 to 7 months, thereby failing to give any serological evidence that the diagnosis was correct. Clinically, all the cases had the typical type of onset and symptoms, including pain and stiffness of the neck and back with pleocytosis of the cerebrospinal fluid. The lack of serological evidence does not invalidate the diagnosis, inasmuch as the majority of cases with frank paralysis also failed to develop protective substances.

\section{SUM MARY}

1. Neutralization tests carried out with the F1 strain (monkey passage) of virus on sera ob- 
tained from paralytic and non-paralytic cases during an outbreak of epidemic proportions gave the following results: (a) Of 82 paralytic cases tested during the acute stage of the disease, the sera of 14 neutralized the virus; (b) 4 of these patients were tested in the preparalytic stage, and the sera of 2 possessed protective bodies; (c) of 32 nonparalytic cases tested in the acute stage of the disease, the sera of 18 neutralized; $(d)$ of 3 encephalitic cases tested in the acute stage, the serum of one neutralized; $(e)$ during convalescence only 2 of 39 paralytics who had no protective substances in the acute stage developed them within a few months after the onset. Two of 24 individuals whose sera had failed previously to neutralize in convalescence developed protective substances 12 to 16 months after the onset; $(f)$ neutralizing substances which had not been present in the acute stage in 11 non-paralytics also failed to develop in the sera tested several months after the onset. One of 5 obtained 12 to 16 months after the onset neutralized; $(g)$ the sera of 2 cases with encephalitic symptoms likewise failed to protect 5 to 6 months after the onset. One which was obtained 12 months after the onset was also negative; $(h)$ two paralytics and one non-paralytic, whose sera neutralized in the acute stage of the disease, failed to show a demonstrable increase of neutralizing substances 2 months or longer after the onset.

2. Sera of 9 of 18 so-called normal individuals, over the age of 10 , neutralized.

3. A strain of virus isolated from the outbreak from which the bloods were collected was tested against the sera and gave results comparable to those obtained with the passage (F1) virus.

4. No evidence of a definite relationship was found between the presence of protective substances in serum and (1) resistance to poliomyelitis, (2) the diagnosis of the non-paralytic form of poliomyelitis and (3) the degree of recovery from paralysis.

The authors wish to express their thanks to Dr. Thomas M. Rivers and to Dr. Morris Schaeffer for their valuable suggestions during the course of this work.

\section{BIBLIOGRAPHY}

1. Netter, A., and Levaditi, C., Action Microbicide Exercée par le sérum des malades atteints de Paralysie Infantile sur le Virus de la Poliomyélite Aigue. Compt. rend. Soc. de biol., 1910, 68, 617.
Action microbicide exercée sur le virus de la poliomyélite aigue par le Sérum des sujets antérieurement atteints de paralysie infantile. Sa constatation dans le serum d'un sujet qui a présenté une forme abortive. Ibid., 1910, 68, 855.

2. Flexner, S., and Lewis, P. A., Experimental poliomyelitis in monkeys. Seventh note: Active immunization and passive serum protection. J. A. M. A., 1910, 54, 1780.

3. Anderson, J. F., and Frost, W. H., Abortive cases of poliomyelitis. An experimental demonstration of specific immune bodies in their blood serum. J. A. M. A., 1911, 56, 663.

4. Peabody, F. W., Draper, G., and Dochez, A. R., A clinical study of acute poliomyelitis. Rockefeller Inst. for Med. Research, Monograph No. 4, 1912.

5. Römer, P. H., Epidemic Infantile Paralysis. Wi1liam Wood and Co., New York, 1913.

6. Kling, C., and Levaditi, C., Etudes sur la Poliomyélite Aigue Epidémique. II. Etat Réfractaire et Propriétés microbicide du sérum. Ann. Inst. Pasteur, 1913, 27, 839.

7. Flexner, S., and Amoss, H. L., The passage of neutralizing substances from the blood into the cerebrospinal fluid in poliomyelitis. J. Exper. Med., 1917, 25, 499.

8. Nuzum, J. W., A study of the neutralizing properties of antipoliomyelitic horse serum (neutralization of virus in vitro). J. Infect. Dis., 1918, 23, 301.

9. Aycock, W. L., and Kramer, S. D., Immunity to poliomyelitis in normal individuals in urban and rural communities as indicated by the neutralization test. J. Prev. Med., 1930, 4, 189.

10. Fairbrother, R. W., and Brown, W. G. S., The action of the serum of normal individuals on the virus of poliomyelitis. Lancet, 1930, 219, 895.

11. Stokes, J., Jr., Wolman, I. J., Carpenter, H. C., and Margolis, J., Prophylactic use of parents' whole blood in anterior poliomyelitis. Philadelphia epidemic of 1932. Am. J. Dis. Child., 1935, 50, 581.

12. Howitt, B. F., Poliomyelitis. Results of in vitro neutralization tests on serums of both treated and untreated poliomyelitis patients. J. Infect. Dis., 1932, 51, 565.

13. Netter, A., and Levaditi, C., Myélites aigues Diffuses et Myélites Transverses Causées par L'Agent de la Paralysie Infantile. Bull. et mém. Soc. méd. d. hôp. de Paris, 1914, 37, 570.

14. Harmon, P. H., Harkins, H. N., Fahey, J. J., and Wasbotten, P. M., Significance of early appearance of neutralizing substances in poliomyelitis of man. Proc. Soc. Exper. Biol. and Med., 1936, 34, 585.

15. Harmon, P. H., and Harkins, H. N., The significance of neutralizing substances in resistance and recovery from poliomyelitis. J. A. M. A., 1936, 107, 552.

16. Shaughnessy, H. J., Harmon, P. H., and Gordon, F. B., The neutralization of poliomyelitis virus by human serum. J. Prev. Med., 1930, 4, 463. 
17. Schultz, E. W., and Gebhardt, L. P., Incidence of "normal" persons possessing demonstrable antibodies for poliomyelitis virus in their serum. Proc. Soc. Exper. Biol. and Med., 1930, 28, 409.

18. Jungeblut, C. W., and Smith, L. W., Blood grouping in poliomyelitis. Its relation to susceptibility and the neutralizing property of convalescent sera. J. Immunol., 1932, 23, 35.

19. Paul, J. R., and Trask, J. D., A comparative study of recently isolated human strains and a passage strain of poliomyelitis virus. J. Exper. Med., 1933, $58,513$.

20a. Jungeblut, C. W., The power of normal human sera to inactivate the virus of poliomyelitis in its relation to blood grouping and to exposure. J. Immunol., 1933, 24, 157.

b. Howitt, B. F., Poliomyelitis in vitro neutralization tests, using normal adult and convalescent human serums. California and West. Med., 1935, 43, 407.

c. Kolmer, J. A., Susceptibility and immunity in relation to vaccination in acute anterior poliomyelitis. J. A. M. A., 1935, 105, 1956.

d. Brodie, M., A comparison between convalescent serum and non-convalescent serum in poliomyelitis. J. Exper. Med., 1932, 56, 507.

21. Paul, J. R., and Trask, J. D., The neutralization test in poliomyelitis. Comparative results with four strains of the virus. J. Exper. Med., 1935, 61, 447.

22. Howitt, B. F., Poliomyelitis. Further studies on the immunization of sheep to the virus of poliomyelitis with a comparison of neutralization tests, using the old and a recent strain of virus. J. Infect. Dis., 1933, 53, 145.

23. Brodie, M., The titration of poliomyelitic virus-containing tissue. J. Immunol., 1933, 25, 87.

24. Jensen, C., The 1934 epidemic of poliomyelitis in Denmark. Preliminary report on the epidemiology, clinical features and convalescent serum therapy. Proc. Roy. Soc. Med., 1935, 28, 1007.

25. Eagles, G. H., Jensen, C., and Henningsen, E. J., The neutralizing value of poliomyelitis convalescent serum from the 1934 epidemic in Denmark. Lancet, 1937, 232, 462.

26. Jungeblut, C. W., and Engle, E. T., Resistance to poliomyelitis. The relative importance of physiologic and immunologic factors. J. A. M. A., 1932, 99, 2091.

27. Schultz, E. W., and Gebhardt, L. P., Observations on the prophylactic value of specific immune serum in experimental poliomyelitis. J. Pediat., 1935, 7, 332.

28. Olitsky, P. K., and Cox, H. R., Experiments on active immunization against experimental poliomyelitis. J. Exper. Med., 1936, 63, 109.

29. Jungeblut, C. W., On the mechanism of immunity in experimental poliomyelitis. J. Infect. Dis., 1936, $58,150$.

30. Sabin, A., and Olitsky, P. K., Humoral antibodies and resistance of vaccinated and convalescent monkeys to poliomyelitis virus. J. Exper. Med., 1936, 64, 739.

31. Brodie, M., Unpublished experiments. 